Д. М. Сатаева [D. M. Sataeva]

О. С. Крайнова [O. S. Kraynova]

УДК

006.83:658.5.012.7

\title{
РАЗРАБОТКА ОТДЕЛЬНЫХ ДОКУМЕНТИРОВАННЫХ ПРОЦЕДУР ХАССП В ОПТИМИЗАЦИИ ЛОГИСТИЧЕСКИХ ПРОЦЕССОВ ОБЕСПЕЧЕНИЯ КАЧЕСТВА ПРОДУКЦИИ И ПОДТВЕРЖДЕНИЯ ЕГО СООТВЕТСТВИЯ ТРЕБОВАНИЯМ РЫНКА
}

\author{
DEVELOPMENT OF SEPARATE DOCUMENTED HACCP PROCEDURES \\ FOR OPTIMIZING LOGISTICS PROCESSES ENSURING PRODUCT QUALITY \\ AND CONFIRMING ITS COMPLIANCE WITH MARKET REQUIREMENTS
}

Институт пищевых технологий и дизайна - филиал ГБОУ ВО «Нижегородский государственный инженерно-экономичсский университет», г. Нижний Новгород, Россия Institute of Food Technologies and Design - Branch of SBEI HE "Nizhny Novgorod State Engineering and Economic University", Nizhny Novgorod, Russia

Анномация. Внедрение системь управления качествои пищевой продукиии на основе приниипов ХАССП, являющееся не только обязательным требованием технического регламента Таможениого союза ТР/TС $021 / 2011$ «O безопасности пицевой продукции", но и стратегическим реиением для организаций пищевой индустрии, направлено на улучиение результатов их деятельности. При этом надлежацим образом оформленная система управления качеством обеспечивает основу для планирования, выполнения, мониторинга и улучиения результатов деятельности. Именно поэтолу одним из облзательных требовапий системы ХАССП является документирование процедур и ведение записей по результатам мониторинга контрольных операций.

Материалы и методы. Для достижения целей, поставленных в работе, применялся иерархический метод классификации, а такље метод "Дерево принятия решений».

Результать. Руководствуясь требованиями стандарта ГОСТ Р 51705.1-2001 и Методическими рекомендациями Федеральной службы по надзору в сфере защить прав потребителей и благополучия человека, разработана структура документированной информации системь ХАССП.

Обсуждение. Эксперимент, составляющий элтирическую базу представленного авторами в статье исследования, предполагал определенное документирование по процедурам, подверженньм анализу на предприятии-производителе продовольственной продукиии.

В соответствии с Планом ХАССП определень критические контрольные точки по отдельньим производственньим прочессам, по результатам мониторинга (контроля) разработан план корректирующих действий для устранения причин несоответствия в случае возникновения отклонений параметров процесса от критических пределов.

Заключение. Предлагаемье в настоящем исследовании способы оптимизации структуры документированной информации системь ХАССП позволяют реиать задачу по созданию нормативной и организационно-методической основы для разработки, внедрения и нормального функционирования в организации системы управления качеством, которая бы в полной мере соответствовала требованиям нормативныхх документов.

Ключевые слова: безопасность, документированная информация, качество, логистический процесс, пищевая продукция, стандарт, ХАССП.

Abstract. The introduction of a food quality management system based on the HACCP principles, which is not only a mandatory requirement of the technical regulation of the Customs Union TR/CU 021/2011 "on food safety", but also a strategic decision for food industry organizations, is aimed at improving the results of their activities. At the same time, a properly designed quality management system provides the basis for planning, implementing, monitoring, and improving performance. That is why one of the mandatory requirements of the HACCP system is to document procedures and keep records of the results of monitoring control operations.

Materials and methods. To achieve the goals set in the work, a hierarchical classification method was used, as well as the "decision Tree" method.

Results. Guided by the requirements of GOST R 51705.1-2001 and the Guidelines of the Federal service for supervision of consumer protection and human well-being, the structure of documented information of the HACCP system was developed.

Discussion. The experiment, which forms the empirical basis of the study presented by the authors in the article, assumed certain documentation on the procedures that are subject to analysis at the food production enterprise.

In accordance with the HACCP Plan, critical control points are defined for individual production processes, and a plan of corrective actions is developed based on the results of monitoring (control) to eliminate the causes of non-compliance in case of deviations of process parameters from critical limits.

Conclusion. The methods proposed in this study to optimize the structure of the documented information of the HACCP system allow us to solve the problem of creating a regulatory and organizational-methodological basis for the development, imple- 
mentation and normal functioning of a quality management system in the organization that would fully meet the requirements of regulatory documents.

Key words: safety, documented information, quality, logistics process, food products, standard, HACCP.

Introduction. Organizations are facing today, and will face tomorrow, fierce global competition, market and law requirements, reduced response times and product life spans. In this situation, the introduction of a food quality management system based on the principles of HACCP (in the English transcription of HACCP - Hazard Analysis and Critical Control Points) [1], which is not only a mandatory requirement of the technical regulation of the Customs Union "On Food Safety" [2], but and a strategic decision for food industry organizations, aimed at improving the results of their activities and providing a solid foundation for sustainable development initiatives [3].

In addition, the implementation of quality management standards is one way or another aimed at creating an effective management system in the supply chain, providing a synergistic effect from the interaction of all market participants [4]. And in this case, the regulation and unification of the requirements and procedures for assessing quality and safety at all stages of product promotion on the market in one way or another will require mechanisms for optimizing the logistics system and all the flows accompanying this movement, aimed at achieving maximum approximation of the aggregate characteristics of the products, considered as material logistics flow, documentation / documentation of quality management procedures - as information and service logistics flows to end-user requirements. And in this regard, the construction of the optimal interaction of participants in the supply chain seems to be the most popular for the authors, and as a tool for this kind of adjustment of the quality management of food products / food products, it reveals the need to implement the principles of HACCP.

Potential benefits from the introduction of a food quality management system based on the principles of HACCP are the following:

- the ability of organizations to stably produce food products and / or provide catering services that meet the requirements of consumers, as well as legislative and regulatory requirements $[5,6,7]$;

- the opportunity to demonstrate compliance of the organization in the field of quality and safety with the requirements set above [8].

This system provides control at all stages of food production, at any point in the process of production, storage and sale of food products, where dangerous situations may arise. When introducing the HACCP system, special attention is paid to critical control points at which, as a result of targeted control measures, all conditions must be created to prevent, eliminate or reduce all types of risks of hazardous factors to an acceptable level.

To implement the HACCP system, manufacturers must not only research their own product and production methods, but also apply this system and its requirements to suppliers of raw materials, auxiliary materials, as well as to the wholesale and retail trade system, i.e. internal and external logistics flows of the considered system of the manufacturer at the level of macro- and mesological system.

A properly designed quality management system provides the basis for planning, implementing, monitoring and improving the results of activities in the provision of food products and food products at the level of micro-, macroand mesological systems. That is why one of the mandatory requirements of the standard GOST R 51705.1-2001 is the documentation of procedures and maintaining records based on the results of monitoring technological operations. The creation and management of documents creates a solid foundation for the organization's processes, while ensuring accountability, risk management and business continuity aimed at optimizing the logistics of material, information, financial, service and work flows.

The purpose of documented information management is to create documents and to manage them in a controlled manner for the efficient implementation of the production activities of the logistics system; ensuring compliance of products with regulatory requirements; decision making optimization; providing protection during litigation related to the presence or lack of evidence of the organization.

Logistic information flows in the form of documents in the quality management system are also designed to provide the necessary information to structural units at the level of the micro-logistics system; mutual understanding between staff; establishing the order of the work; providing the basis for the training of newly hired employees and the necessary retraining of all personnel of the organization; creating the basis for the audit of the HACCP system [9].

Requirements for documenting all procedures, forms and methods of recording data related to the HACCP system are established in paragraph 3 of the standard [1], and provide a structured approach to document management.

Materials and Methods. To achieve the goals set in the work, a hierarchical classification method was used [10], as well as the "decision Tree" method [1].

Results. The volume and composition of the documented information of the logistics systems of various organizations may differ depending on the size of the organization and the type of its activity, the range of products and / or services provided, the complexity of the processes, and, of course, the competence of employees. At the same time, guided by the requirements of the standards GOST R 51705.1-2001 [1], GOST R 56671-2015 [11] and the Methodological recommendations of the Federal Service for Supervision of Consumer Rights Protection and Human Well-being [12], in organizing the creation and functioning of the management system quality based on the principles of HACCP must necessarily be developed and managed information presented in table 1 . 
Elements of a quality management system based on the principles of HACCP to be documented [Compiled by the authors]

\begin{tabular}{|c|c|}
\hline $\begin{array}{l}\text { Clause of GOST } \\
\text { R 51705.1-2001 } \\
\text { standard }\end{array}$ & Name of the document (example) \\
\hline 4.1 .2 & Policy in the field of quality and safety of food products; organizational structure of the enterprise \\
\hline 4.1 .3 & An assortment of products with an indication of the document in accordance with which it is produced \\
\hline 4.1 .4 & Order on the establishment of the HACCP group \\
\hline 4.1.4.1 & Documents confirming the competence of employees (documents on education and work experience); staff training plan \\
\hline 4.1 .4 .4 & HACCP Group Minutes \\
\hline 4.2 .1 & $\begin{array}{l}\text { Regulatory documents for products, raw materials, food additives and packaging (GOST, GOST R, STO, TU); assortment list of } \\
\text { products }\end{array}$ \\
\hline 4.2.2.1 & $\begin{array}{l}\text { Flowchart of the production process; technological instructions; technical and technological maps; layout of production facilities } \\
\text { with the location of equipment; flow route diagrams; cross-pollution management instructions; technology magazines }\end{array}$ \\
\hline 4.2.2.2 & $\begin{array}{l}\text { Production control program; instructions on cleaning, disinfection and deaeration procedures, staff hygiene; instructions for handling } \\
\text { allergens, genetically modified organisms (GMOs), the use of food additives; an input control journal or acceptance sheets with a } \\
\text { mandatory assessment of the conditions of transportation and delivery of raw materials; regulatory documents for raw materials, } \\
\text { ingredients, packaging materials; documents confirming the safety of raw materials, packaging and auxiliary materials; instructions } \\
\text { or documented procedures for the incoming inspection of raw materials, ingredients, packaging materials; documented procedure } \\
\text { "Management of non-conforming products"; temperature and humidity control log; personal medical book of the forwarding driver; } \\
\text { list of specialized vehicles; agreements for the washing and disinfection of vehicles with acts of delivery of acceptance of work per- } \\
\text { formed; contract for the provision of transport services in the case of the use of hired vehicles }\end{array}$ \\
\hline 4.2 .3 & HACCP Compliance Monitoring Protocol \\
\hline 4.3 .1 & $\begin{array}{l}\text { Normative documents regulating product safety; HACCP plan; laboratory research protocols; health and examination logs; in- } \\
\text { structions for observing the rules of personal hygiene; instructions for accessing third-party visitors to the enterprise; contract for } \\
\text { medical examination of employees and other documents }\end{array}$ \\
\hline 4.3 .2 & $\begin{array}{l}\text { HACCP Plan; laboratory research protocols; Complaints, claims, complaints and incidents related to violation of product safety } \\
\text { requirements }\end{array}$ \\
\hline 4.3 .3 & Preventive action plan \\
\hline 4.4 .4 & HACCP Plan; laboratory research protocols \\
\hline $4.5 .1-4.5 .4$ & HACCP Plan \\
\hline 4.6 .1 & HACCP plan, production control program \\
\hline 4.6 .3 & HACCP Plan; technology magazine \\
\hline $4.7 .1-4.7 .5$ & $\begin{array}{l}\text { Procedure "Management of non-conforming products"; HACCP worksheet; preventive action plan; approved lists of test equip- } \\
\text { ment and measuring instruments; schedule of verification and certification of equipment and measuring instruments, verification } \\
\text { certificate; equipment maintenance contracts; instruction "Requirements for measuring and control devices"; schedule of preven- } \\
\text { tive maintenance, instructions for preventive and maintenance; technical passports, documents confirming permission to use } \\
\text { equipment for contact with food; equipment technical inspection log }\end{array}$ \\
\hline 4.7 .4 & Potentially hazardous product recall procedure \\
\hline $4.8 .1-4.8 .3$ & $\begin{array}{l}\text { Procedure for internal audits (inspections) of the HACCP system; program of internal audits (inspections); report on internal } \\
\text { audits (inspections) }\end{array}$ \\
\hline 4.9.1,4.9.2 & The list of registration documentation of the quality management system based on the principles of HACCP \\
\hline 4.9 .3 & Procedure "HACCP System Documentation Management" \\
\hline
\end{tabular}

The structure of the interaction of documents of the quality management system of the logistics system based on the principles of HACCP, according to the authors, can be composed in the form of a hierarchy in which each subsequent level clarifies but does not duplicate the previous one, optimizing information and service logistics flows. Such a construction contributes to the implementation, maintenance and better understanding of documentation requirements by the staff, as well as the formation of a knowledge base, as one of the competitive advantages of the organization [13]. In general, the structure of the external and internal documented information of the organization can be represented in the form of a diagram (Fig. 1). The structure shows the importance of documents when moving from the upper level to the lower. This means that when developing documents, you should adhere to the rules:

- the document of the lower level should not contradict the requirements of documents occupying the top positions;

- documents of the lower level should not duplicate the information contained in the documents occupying the top positions, but should contain links to them.

In turn, the organization's use of external regulatory documentation at the stages of the product life cycle (communication with the consumer, development, preparation of production, procurement, production and sale) is carried out in order to increase the level of safety; ensuring competitiveness, rational use of resources and customer requirements; confirmation of product conformity; court decisions; fulfillment of deliveries. Therefore, if necessary, and in order to limit the number of internal documentation, its development and updating should include links to existing external regulatory documents. 


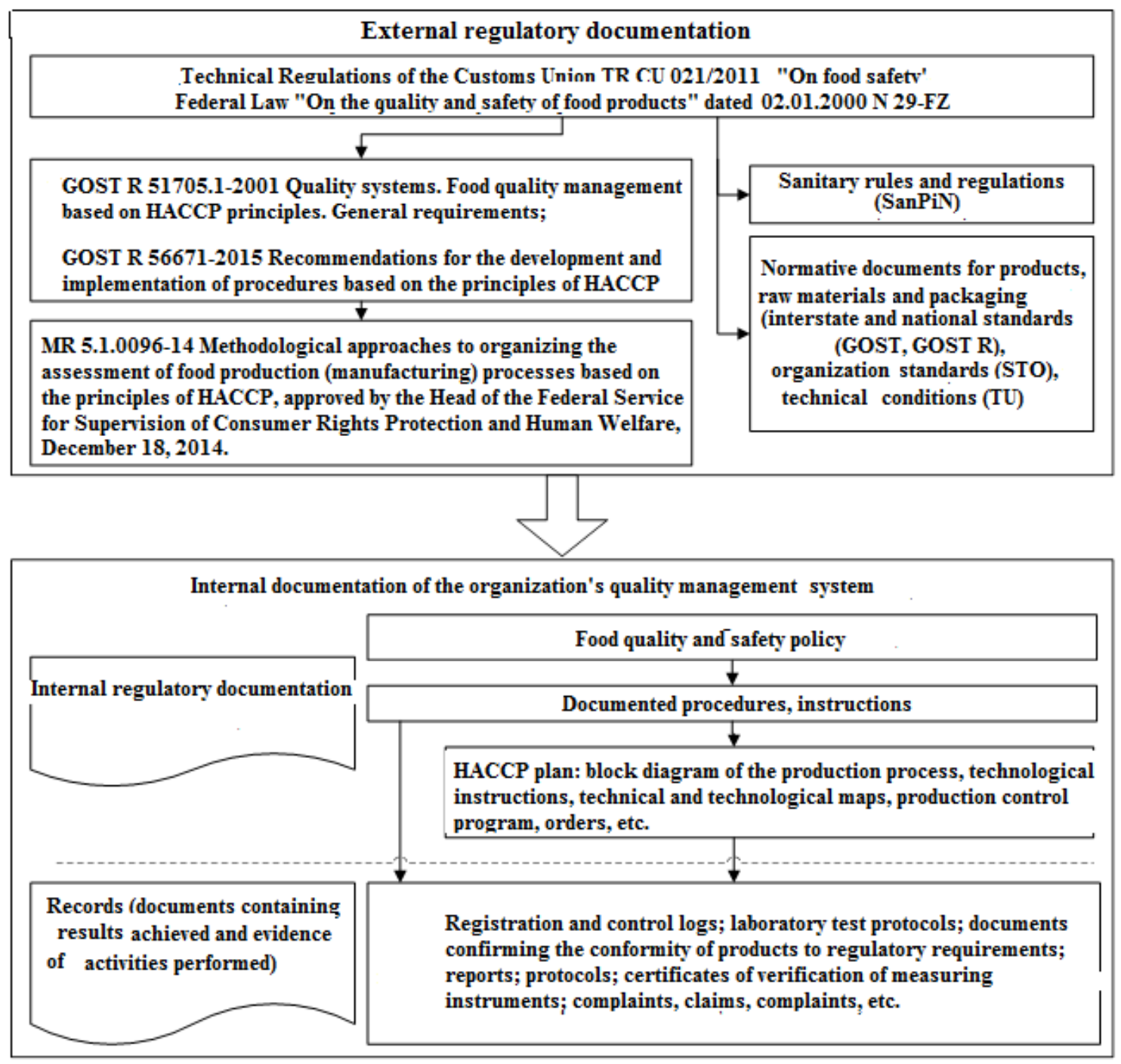

Fig. 1. Structure of the external and internal documented information of the HACCP system [Compiled by the authors]

Documented information recorded and stored as evidence of conformity (records), for example, test reports, control logs, etc., must be protected from unintentional changes. As for the term "record" referred to in ISO 9001: 2008 [14] and used to indicate the documents necessary for recording the results of an organization's activities and present evidence of its compliance with established requirements, the requirement "register" is used in version ISO 9001: 2015 [11] and keep documented information".

However, the use in the organization of the terms "document" and "record" habitual for it is not excluded and can be implemented depending on the rules for identifying documents established by the organization.

A record is a document containing the results achieved or evidence of activities undertaken. The presence and preservation of them in the organization is evidence of the functioning of the HACCP system both for the management of the organization and for external auditors.

The main task of managing records is to ensure the safety and convenience of finding the necessary information about the results of processes. Records are kept and maintained in working order to obtain evidence of product compliance with established requirements and the effectiveness of the HACCP system at all stages of the product life cycle.

The forms of document forms for maintaining quality records, the procedure for filling them out and the responsibility for filling out should be established in the HACCP system documentation management procedure.

The authenticity and reliability of all quality data should be certified by a signature with a transcript of the name of the person responsible for entering the quality data.

Quality records are kept in the units where they are collected. Storage conditions for documents in the unit should ensure their safety, absence of damage and prevention of damage during the entire storage period. Recovery of quality data in the event of loss of paper copies can be made from an electronic database. 
Access to records is granted with the permission of the heads of departments responsible for their storage. Granting access to consumers and suppliers to documents containing quality records is carried out in accordance with the requirements of the agreement (contract).

The main stages of record management are presented in table 2.

Stages and means of record management [Compiled by the authors according to the methodology of developing

a quality management system: Business Studio help system. URL: http://www.businessstudio.ru [15]

\begin{tabular}{|c|c|c|}
\hline $\mathbf{N} \Pi / \Pi$ & Management stage & Management tools \\
\hline 1 & \multicolumn{2}{|l|}{ Formation } \\
\hline 1.1 & \multicolumn{2}{|c|}{ Determining which records, when and how should be generated } \\
\hline 1.1 .1 & Identification of information needs & $\begin{array}{l}\text { All operational, reporting data on the organization's processes should be systematically iden- } \\
\text { tified and documented. }\end{array}$ \\
\hline 1.1 .2 & Definition of requirements & $\begin{array}{l}\text { Requirements for the formation, generalization and accounting of records should be deter- } \\
\text { mined on the basis of legislative and other requirements }\end{array}$ \\
\hline 1.1 .3 & Creation of reliable records & Records should be formed at the time (or shortly after) of the operation to which they relate \\
\hline 1.1 .4 & Determination of shelf life & $\begin{array}{l}\text { A guidance document should be developed establishing the procedure for determining the } \\
\text { retention periods of records as required }\end{array}$ \\
\hline 2 & \multicolumn{2}{|l|}{ Control } \\
\hline 2.1 & \multicolumn{2}{|c|}{ Determining what information should be generated from the records and how it will be managed over time } \\
\hline 2.1 .1 & Registration & $\begin{array}{l}\text { For processes requiring evidence of data collection, a guidance document should be devel- } \\
\text { oped that establishes the procedure for registering records by assigning them an individual } \\
\text { number and date of creation }\end{array}$ \\
\hline 2.2 & \multicolumn{2}{|c|}{ Establishing Terms and Conditions for Using Records Over Time } \\
\hline 2.2 .1 & Development of Access Rules & Record Access Rules must be defined. \\
\hline 2.2 .2 & Implementing Access Rules & $\begin{array}{l}\text { Access Rules must be implemented in record systems by assigning access status to both } \\
\text { records and performers }\end{array}$ \\
\hline 2.3 & \multicolumn{2}{|l|}{ Keeping records usable over time } \\
\hline 2.3 .1 & Maintaining integrity & $\begin{array}{l}\text { A procedure must be established to ensure the integrity and protection of records and to } \\
\text { prevent unauthorized use, amendment, removal, concealment and (or) destruction }\end{array}$ \\
\hline 2.3 .2 & $\begin{array}{l}\text { Ensuring accessibility and } \\
\text { usefulness }\end{array}$ & $\begin{array}{l}\text { The procedure for ensuring the availability and usefulness of digital recordings over time } \\
\text { should be defined. }\end{array}$ \\
\hline 2.4 & \multicolumn{2}{|c|}{ Implementation of authorized removal of records from circulation } \\
\hline 2.4 .1 & Withdrawal from circulation & $\begin{array}{l}\text { The procedure for analysis, authorization and implementation of decisions regarding the } \\
\text { preservation and removal of entries from circulation for each work process should be defined }\end{array}$ \\
\hline 2.4 .2 & Broadcast & $\begin{array}{l}\text { The procedure for authorized and controlled transfer of records to another organization } \\
\text { should be established. }\end{array}$ \\
\hline 2.4 .4 & $\begin{array}{l}\text { Saving information about destroyed } \\
\text { records }\end{array}$ & $\begin{array}{l}\text { In cases where the nature and complexity of the activity and official record keeping require } \\
\text { this, information (registration, identification and chronological metadata) about records that } \\
\text { have been destroyed must be preserved }\end{array}$ \\
\hline
\end{tabular}

Discussion. The experiment, which constitutes the empirical basis of the study presented by the authors in the article, suggested some documentation on the procedures that are subject to analysis at the enterprise manufacturing food products.

Initially, the authors need, in accordance with the main document, the HACCP Plan, to determine the critical control points (hereinafter - CCP) for individual production processes (Table 3 ).

Critical Control Points for Procedures under the HACCP Plan of a Food Producer [Compiled by the authors]

\begin{tabular}{|l|l|l|l|l|}
\hline \multicolumn{1}{|c|}{ Stages } & KKT & \multicolumn{1}{c|}{ Hazard / risk } & \multicolumn{1}{c|}{$\begin{array}{c}\text { Preventive actions / } \\
\text { management activities }\end{array}$} \\
\hline $\begin{array}{l}\text { 1. Weighing } \\
\text { ingredients }\end{array}$ & KKT 1 & Excessive Vitamin Premix & Formulation Compliance \\
\hline $\begin{array}{l}\text { 2. Filtration } \\
\text { of feedstock }\end{array}$ & KKT 2 & $\begin{array}{l}\text { Physical: foreign matter due to inappropriate } \\
\text { filter cell size or filter integrity }\end{array}$ & $\begin{array}{l}\text { 1. Compliance with the frequency of } \\
\text { inspection of mechanical filters. }\end{array}$ & 1. Appropriate filter cell size. \\
\hline 3. Sterilization & KKT 3 & $\begin{array}{l}\text { Microbiological: survival of extraneous } \\
\text { microflora (pathogenic, conditionally patho- } \\
\text { genic microorganisms). Due to insufficient } \\
\text { sterilization temperature }\end{array}$ & $\begin{array}{l}\text { 2. Removal of possible foreign parti- } \\
\text { cles from the filter. }\end{array}$ & 2. The integrity of the filter. \\
\hline 4. Sterilization & KKT 4 & $\begin{array}{l}\text { Microbiological: survival of extraneous } \\
\text { microflora (pathogenic, conditionally patho- } \\
\text { genic microorganisms) due to insufficient } \\
\text { exposure time }\end{array}$ & $\begin{array}{l}\text { 3. Conducting scheduled preventive } \\
\text { repairs (hereinafter - PPR) and mainte- } \\
\text { nance (hereinafter - MOT) of equip- } \\
\text { ment. }\end{array}$ & $\begin{array}{l}\text { Temperature in the set pa- } \\
\text { rameters }\end{array}$ \\
\hline
\end{tabular}

As a result of audits, surveys, and expert evaluations of both the actual and estimated state of the enterprise's logistics system, one way or another, inconsistencies with plans, programs, and other documentations may arise. De- 
pending on the nature of these inconsistencies and on whether they are potential or already detected, either preventive or corrective actions are applied to them. The developed system of corrective actions based on the results of monitoring (control) during technological operations, reflected in table 4 , is presented in table 5.

Table 4

Monitoring of procedures under the HACCP plan [Compiled by the authors]

\begin{tabular}{|l|l|l|l|l|}
\hline \multicolumn{1}{|c|}{ Stage } & \multicolumn{3}{|c|}{ Monitoring (control) } \\
\cline { 2 - 5 } & Subject / place of control & \multicolumn{1}{c|}{ Method / Procedure } & \multicolumn{1}{c|}{ Periodicity } \\
\hline $\begin{array}{l}\text { 1. Weighing } \\
\text { ingredients }\end{array}$ & Vitamin Premix Weight & $\begin{array}{l}\text { 1. The working calibration of the } \\
\text { scales, calibrated according to the } \\
\text { inspection schedule. }\end{array}$ & During each weighing \\
\hline $\begin{array}{l}\text { 2. Filtration of } \\
\text { feedstock }\end{array}$ & Mechanical filter & 2. Weight control premix vitamin. & $\begin{array}{l}\text { Visual inspection at the end of } \\
\text { the process, immediately before } \\
\text { the } \\
\text { automatic washing of the } \\
\text { heat exchanger, but at least once } \\
\text { a day } \\
\text { washing of mechanical } \\
\text { filters }\end{array}$ \\
\hline 3. Sterilization & Sterilization temperature & Visual inspection & $\begin{array}{l}\text { During each sterilization cycle } \\
\text { (beginning, middle, end) }\end{array}$ & $\begin{array}{l}\text { Thermogram } \\
\text { (automatically) }\end{array}$ \\
\hline 4. Sterilization & Installation performance & $\begin{array}{l}\text { and Visually by the temperature } \\
\text { sensor on the monitor. }\end{array}$ & $\begin{array}{l}\text { During each sterilization cycle } \\
\text { (beginning, middle, end) }\end{array}$ & $\begin{array}{l}\text { Log book of equip- } \\
\text { ment operating mode }\end{array}$ \\
\hline
\end{tabular}

Table 5

Corrective actions based on monitoring results on procedures under the HACCP plan [Compiled by the authors]

\begin{tabular}{|c|c|c|c|c|}
\hline \multirow{2}{*}{ Stage } & \multicolumn{3}{|c|}{ Correction and Corrective Action } & \multirow{2}{*}{$\begin{array}{c}\text { Verification } \\
\text { (confirmation) }\end{array}$} \\
\hline & Method / Procedure & Responsible person & Data logging & \\
\hline $\begin{array}{l}\text { 1. Weighing } \\
\text { ingredients }\end{array}$ & 1. Recalibrate the balance. & Process Engineer & Ingredient Sheet & $\begin{array}{l}\text { Checking the ingredient } \\
\text { sheet after each production } \\
\text { process, by internal auditors } \\
\text { during the internal audit }\end{array}$ \\
\hline \multirow{10}{*}{$\begin{array}{l}\text { 2. Filtration } \\
\text { of feedstock }\end{array}$} & \multicolumn{3}{|l|}{ Correction } & \multirow{10}{*}{$\begin{array}{l}\text { Review of records on the } \\
\text { control of mechanical filters } \\
\text { by members of the HACCP } \\
\text { group during weekly walks, } \\
\text { by internal auditors during } \\
\text { the internal audit }\end{array}$} \\
\hline & 1. Clean and rinse the filter. & Process Engineer & $\begin{array}{l}\text { Log of inspection and } \\
\text { cleaning of mechanical } \\
\text { filters }\end{array}$ & \\
\hline & $\begin{array}{l}\text { 2. Notify the site master (within } 5 \text { minutes } \\
\text { after detecting a discrepancy). }\end{array}$ & Process Engineer & Orally & \\
\hline & $\begin{array}{l}\text { 3. Block products developed since the last } \\
\text { positive control of the filter. }\end{array}$ & $\begin{array}{l}\text { Quality Control } \\
\text { Engineer }\end{array}$ & Signal sheet & \\
\hline & 4. Make a decision on blocked products. & $\begin{array}{l}\text { Head of Technical } \\
\text { Control Department, } \\
\text { Production Manager }\end{array}$ & Act of destruction & \\
\hline & $\begin{array}{l}\text { 5. Make a record of the departure of the } \\
\text { CCP beyond the limits and a record of the } \\
\text { correction (within } 30 \text { minutes after detect- } \\
\text { ing a discrepancy). }\end{array}$ & Process Engineer & $\begin{array}{l}\text { 1. Journal of inspection } \\
\text { and cleaning of mechani- } \\
\text { cal filters. }\end{array}$ & \\
\hline & $\begin{array}{l}\text { 6. Replace the filter (until the next batch } \\
\text { of product is released). }\end{array}$ & Service Engineer & $\begin{array}{l}\text { 2. An e-mail addressed to } \\
\text { the master of the site } \\
\text { about the exit of the CCP } \\
\text { beyond. }\end{array}$ & \\
\hline & $\begin{array}{l}\text { Corrective action: } \\
\text { 1. Investigate the causes of non- } \\
\text { compliance. } \\
\text { 2. Take measures to eliminate the cause of } \\
\text { non-compliance (based on the results of } \\
\text { the investigation). }\end{array}$ & Service Engineer & Application for work & \\
\hline & $\begin{array}{l}\text { 3. Inform the representative of the } \\
\text { HACCP group. }\end{array}$ & \multirow[t]{2}{*}{ Shift Supervisor } & & \\
\hline & $\begin{array}{l}\text { 4. Make a record based on the results of } \\
\text { corrective actions. }\end{array}$ & & & \\
\hline 3. Sterilization & \multicolumn{3}{|l|}{ Correction: } & \\
\hline
\end{tabular}




\begin{tabular}{|c|c|c|c|c|}
\hline \multirow{6}{*}{$\begin{array}{l}\text { Stage } \\
(\mathrm{CCP} 3)\end{array}$} & \multicolumn{3}{|c|}{ Correction and Corrective Action } & \multirow{6}{*}{$\begin{array}{l}\text { Verification } \\
\text { (confirmation) }\end{array}$} \\
\hline & Method / Procedure & Responsible person & Data logging & \\
\hline & $\begin{array}{l}\text { 1. Return to reprocessing in production. } \\
\text { 2. Notify the site master (within } 5 \text { minutes } \\
\text { after detecting a discrepancy). } \\
\text { 3. Make a record of the departure of the } \\
\text { CCP beyond the limits and a record of the } \\
\text { correction (within } 30 \text { minutes after detect- } \\
\text { ing a discrepancy). }\end{array}$ & Process Engineer & $\begin{array}{l}\text { 1. Thermogram (automat- } \\
\text { ically). } \\
\text { 2. Report on the operation } \\
\text { of the equipment. } \\
\text { 3. E-mail in the name of } \\
\text { the master of the site } \\
\text { about the exit of the CCP } \\
\text { beyond. }\end{array}$ & \\
\hline & \multicolumn{3}{|l|}{ Corrective action: } & \\
\hline & $\begin{array}{l}\text { 1. Identify the causes of the temperature } \\
\text { drop. } \\
\text { 2. Develop and implement measures to } \\
\text { eliminate the cause of non-compliance. }\end{array}$ & $\begin{array}{l}\text { Service Engineer, } \\
\text { Process Engineer }\end{array}$ & Application for work & \\
\hline & $\begin{array}{l}\text { 3. Inform the representative of the } \\
\text { HACCP group. } \\
\text { 4. Make a record based on the results of } \\
\text { corrective actions. }\end{array}$ & Shift Supervisor & E-mail & \\
\hline \multirow{2}{*}{$\begin{array}{l}\text { 4. Sterilization } \\
\text { (KKT 4) }\end{array}$} & \multicolumn{3}{|l|}{ Correction: } & \multirow[b]{2}{*}{$\begin{array}{l}\text { Verification of correction } \\
\text { records by members of the } \\
\text { HACCP group during } \\
\text { weekly walks, by internal } \\
\text { audits during the internal } \\
\text { audit }\end{array}$} \\
\hline & $\begin{array}{l}\text { 1. Return to reprocessing in production. } \\
\text { 2. Notify the site master (within } 5 \text { minutes } \\
\text { after detecting a discrepancy). } \\
\text { 3. Make a record of the departure of the } \\
\text { CCP beyond the limits and a record of } \\
\text { correction (within } 30 \text { minutes after the } \\
\text { detection of a discrepancy) }\end{array}$ & Process Engineer & $\begin{array}{l}\text { 1. Report on the operation } \\
\text { of the equipment. } \\
\text { 2. An e-mail addressed to } \\
\text { the master of the site } \\
\text { about the exit of the CCP } \\
\text { beyond. }\end{array}$ & \\
\hline
\end{tabular}

Conclusion. Detailed documentation of the quality management system should be carried out so that the system remains understandable not only for those who developed it, but also for employees of the organization itself, as well as third-party organizations: suppliers, consumers, control bodies, thus ensuring optimization of the flows of all participants in the logistics supply chain [16].

The methods of optimizing the structure of the documented information of the HACCP system proposed in this study allow us to solve the problem of creating a regulatory and organizational-methodological basis for the development, implementation and normal functioning of a quality management system in an organization that would fully comply with the requirements of regulatory documents.

In view of the presence of sufficient advantages of documenting the procedures of the HACCP system, one should not forget about their information support based on modern procedures for optimizing the logistics system of enterprises in terms of their information subsystem. And this implies the widespread use of information technology of the decision support class, which includes interactive informatization systems for the implementation of support, covering the main stages of document management. According to the authors, it is advisable to consider further research into the issues of ensuring quality management procedures as optimization of the logistics information system, including (in the definitions of logistics) various information flows circulating inside and between elements of the logistics system, between the logistics system and the external environment [17]. Thus, the effectiveness of the logistics system is achieved only if the HACCP principles are integrated into existing production processes, including by creating the optimal information base for the quality management system [18].

\section{ЛИТЕРАТУРА}

1. ГОСТ Р 51705.1-2001. Государственный стандарт Российской Федерации. Системы качества. Управление качеством пищевых продуктов на основе принципов ХАССП. Общие требования (принят и введен в действие Постановлением Госстандарта России от 23.01.2001 N 31-ст). URL: http:/www.consultant.ru/cons/cgi/online.cgi?req=doc\&base $=\mathrm{OTN} \& \mathrm{n}=2228 \# 08123886766365136$ (дата обращения: 05.01.2020).

2. Технический регламент Таможенного союза ТР ТС 021/2011 «О безопасности пищевой продукции» (принят и введен в действие рештением Комиссии Таможенного союза от 9 декабря 2011 года N 880) URL: http://docs.cntd.ru/document $/ 902320560$ (дата обращения: 05.01.2020).

3. Limareva N.S., Shaltumaev T.S., Shchedrina T.V., Orobinskaya V.N. European trends in providing food safety in training of technology students in conditions of the development of digital technologies. В сборнике: IOP Conference Series: Materials Science and Engineering. 2019. C. 012100.

4. Горячева И.А., Трегубов В.Н. К вопросу терминологического определения уязвимости цепи поставок: факторы, причины и формирование адаптивной модели управления // Логистика и управление цепями поставок. 2019. № 3 (92). С. 11-17.

5. Маюрникова Л.А., Губаненко Г.А., Кокшаров А.А. ХАССП на предприятиях общественного питания. Кемеровский государственный университет, Сибирский федеральный университет. Санкт-Петербург, 2019.

6. Павлова Л.В. Обеспечение катества продукции посредством применения стандартов организаций // Научнометодический электронный журнал «Концепт». 2017. Т. 2. С. 79-83. URL: http://e-koncept.ru/2017/570019.htm (дата обращения: 08.01.2020). 
7. Кожахметова А.Н., Петрова Е.И., Вершинина В.С. Система ХАССП на пищевых предприятиях // Наука в современном мире: приоритеты развития. 2018. Т. 2. № 1 (4). С. 20-22.

8. Shchedrina T.V., Limareva N.S., Malakhov V.B., Orobinskaya V.N., Shaltumaev T.Sh. Safety of products and services in the modern catering sector // Современная наука и инновации. 2019. № 1 (25). С. 115-119.

9. Крайнова О.С., Горячева И.А. Технология оценки сформированности компетенций в области менеджмента качества .логистических процессов // Инновационная деятельность. 2019. №3(50). С. 31-40.

10. РД 50-699-90 Методические указания. Надежность в технике. Общие правила классификации отказов и предельных состояний. URL: http://gostrf.com/normadata/1/4294847/4294847529.pdf. (дата обращения: 05.01.2020)

11. ГОСТ Р 56671-2015. Национальный стандарт Российской Федерации. Рекомендации по разработке и внедрению процедур, основанных на принципах ХАССП (утв. и введен в действие Приказом Росстандарта от $23.10 .2015 \mathrm{~N}$ 1627-ст). URL: http://www.consultant.ru/cons/cgi/online.cgi?req=doc\&base=OTN\&n=10337\#05231651728565221f (дата обращения: 10.01 .2020 ).

12. МР 5.1.0096-14 Методические подходы к организации оценки процессов производства (изготовления) пищевой продукции на основе принципов ХАССП: методические рекомендации (утв. руководителем Федеральной службы по надзору в сфере защиты прав потребителей и благополучия человека, Главным государственным санитарным врачом РФ 18 декабря 2014 года.). URL: http://docs.cntd.ru/document/1200124841 (дата обрапения: 10.01.2020).

13. Сатаева Д.М., Павлова Л.В., Маковеев А.Г. Внедрение менеджмента знаний в организационную структуру компаний // Стандарты и качество. 2018. № 5. С. 62-65.

14. ГОСТ Р ИСО 9001-2008. Системы менеджмента качества. Требования (утв. и введен в действие Приказом Федерального агентства по техническому регулированию и метрологии от 18 декабря 2008 г. N 471-ст). URL: $\mathrm{http}: / /$ docs.cntd.ru/document/1200068732 (дата обрапения: 10.01.2020).

15. Методика разработки системы менеджмента качества: система справки программы Business Studio. URL: http://www.businessstudio.ru (дата обращения: 10.01.2020).

16. Сатаева Д.М. Управ.ение документированной информацией: подход на основе ISO 9001:2015 // Вестник Волжской государственной академии водного транспорта. 2018. № 55. С. 100-110.

17. Крайнова О.С. Маркетинговое сопровождение оптимизации .огистической системы. М.: изд. «МУ им. С.Ю. Витте». 2019. 145 с

18. Геращенко А.А., Гончарова А.П. Информационные системы в коммерческой логистике: опыт применения // Образование и наука без границ: социально-гуманитарные науки. 2018. № 10. С. 37-40.

\section{REFERENCES}

1. GOST R 51705.1-2001. Gosudarstvennyy standart Rossiyskoy Federatsii. Sistemy kachestva. Upravlenie kachestvom pishchevykh produktov na osnove printsipov KHASSP. Obshchie trebovaniya (prinyat $\mathrm{i}$ vveden $\mathrm{v}$ deystvie Postanovleniem Gosstandarta Rossii ot 23.01.2001 N 31-st). URL: http://www.consultant.ru/cons/cgi/online.cgi?req=doc\&base=OTN\&n=2228\#08123886766365136 (data obrashcheniya: 05.01.2020).

2. Tekhnicheskiy reglament Tamozhennogo soyuza TR TS $021 / 2011$ «O bezopasnosti pishchevoy produktsii» (prinyat $\mathrm{i}$ vveden $\mathrm{v}$ deystvie resheniem Komissii Tamozhennogo soyuza ot 9 dekabrya 2011 goda N 880) URL: http://docs.cntd.ru/document/902320560 (data obrashcheniya: 05.01.2020)

3. Limareva N.S., Shaltumaev T.S., Shchedrina T.V., Orobinskaya V.N. European trends in providing food safety in training of technology students in conditions of the development of digital technologies. V sbornike: IOP Conference Series: Materials Science and Engineering. 2019. S. 012100.

4. Goryacheva I.A., Tregubov V.N. K voprosu terminologicheskogo opredeleniya uyazvimosti tsepi postavok: faktory, prichiny $i$ formirovanie adaptivnoy modeli upravleniya // Logistika i upravlenie tsepyami postavok. 2019. № 3 (92). S. 11-17.

5. Mayurnikova L.A., Gubanenko G.A., Koksharov A.A. KHASSP na predpriyatiyakh obshchestvennogo pitaniya. Kemerovskiy gosudarstvennyy universitet, Sibirskiy federal'nyy universitet. Sankt-Peterburg, 2019.

6. Pavlova L.V. Obespechenie kachestva produktsii posredstvom primeneniya standartov organizatsiy // Nauchnometodicheskiy ehlektronnyy zhurnal «Kontsept». 2017. T. 2. S. 79-83. URL: http://e-koncept.ru/2017/570019.htm (data obrashcheniya: 08.01.2020).

7. Kozhakhmetova A.N., Petrova E.I., Vershinina V.S. Sistema KHASSP na pishchevykh predpriyatiyakh // Nauka v sovremennom mire: prioritety razvitiya. 2018. T. 2. № 1 (4). S. 20-22.

8. Shchedrina T.V., Limareva N.S., Malakhov V.B., Orobinskaya V.N., Shaltumaev T.Sh. Safety of products and services in the modern catering sector // Sovremennaya nauka i innovatsii. 2019. № 1 (25). S. 115-119.

9. Kraynova O.S., Goryacheva I.A. Tekhnologiya otsenki sformirovannosti kompetentsiy v oblasti menedzhmenta kachestva logisticheskikh protsessov // Innovatsionnaya deyatel'nost'. 2019. №3(50). S. 31-40.

10. RD 50-699-90 Metodicheskie ukazaniya. Nadezhnost' v tekhnike. Obshchie pravila klassifikatsii otkazov i predel'nykh sostoyaniy. URL: http://gostrf.com/normadata/1/4294847/4294847529.pdf. (data obrashcheniya: 05.01.2020)

11. GOST R 56671-2015. Natsional'nyy standart Rossiyskoy Federatsii. Rekomendatsii po razrabotke i vnedreniyu protsedur, osnovannykh na printsipakh KHASSP (utv. i vveden v deystvie Prikazom Rosstandarta ot 23.10.2015 N 1627-st). URL: http://www.consultant.ru/cons/cgi/online.cgi?req=doc\&base=OTN\&n=10337\#05231651728565221f (data obrashcheniya: 10.01.2020).

12. MP 5.1.0096-14 Metodicheskie podkhody k organizatsii otsenki protsessov proizvodstva (izgotovleniya) pishchevoy produktsii na osnove printsipov KHASSP: metodicheskie rekomendatsii (utv. rukovoditelem Federal'noy sluzhby po nadzoru v sfere zashchity prav potrebiteley i blagopoluchiya cheloveka, Glavnym gosudarstvennym sanitarnym vrachom RF 18 dekabrya 2014 goda.). URL: http://docs.cntd.ru/document/1200124841 (data obrashcheniya: 10.01.2020).

13. Sataeva D.M., Pavlova L.V., Makoveev A.G. Vnedrenie menedzhmenta znaniy v organizatsionnuyu strukturu kompaniy // Standarty i kachestvo. 2018. № 5. S. 62-65. 
14. GOST R ISO 9001-2008. Sistemy menedzhmenta kachestva. Trebovaniya (utv. i vveden v deystvie Prikazom Federal'nogo agentstva po tekhnicheskomu regulirovaniyu i metrologii ot 18 dekabrya 2008 g. N 471-st). URL: http://docs.cntd.ru/document/1200068732 (data obrashcheniya: 10.01.2020).

15. Metodika razrabotki sistemy menedzhmenta kachestva: sistema spravki programmy Business Studio. URL: http://www.businessstudio.ru (data obrashcheniya: 10.01.2020).

16. Sataeva D.M. Upravlenie dokumentirovannoy informatsiey: podkhod na osnove ISO 9001:2015 // Vestnik Volzhskoy gosudarstvennoy akademii vodnogo transporta. 2018. № 55. S. 100-110.

17. Kraynova O.S. Marketingovoe soprovozhdenie optimizatsii logisticheskoy sistemy. M.: izd. «MU im. S.YU. Vitte». 2019. $145 \mathrm{~s}$

18. Gerashchenko A.A., Goncharova A.P. Informatsionnye sistemy v kommercheskoy logistike: opyt primeneniya // Obrazovanie i nauka bez granits: sotsial'no-gumanitarnye nauki. 2018. № 10. S. 37-40.

\section{OБ ABTOPAX | ABOUT AUTHORS}

Сатаева Диана Михай.товна, кандидат технических наук, доцент, декан технологического факультета Института пищевых технологий и дизайна - филиала ГБОУ ВО «Нижегородский государственный инженерно-экономический университет» г. Нижний Новгород. Контакты: e-mail: smu_nngasu@mail.ru Sataeva Diana Mikhailovna, Candidate of Technical Sciences, Associate Professor, Dean of the technology faculty of the Institute of food technologies and design - a branch of the Nizhny Novgorod state University of engineering and Economics. Contacts: e-mail: smu_nngasu@mail.ru

Крайнова О.пьа Сергеевна, канд. экон. наук, доцент Института пищевых технологий и дизайна филиала ГБОУ ВО «Нижегородский государственшый инженерно-экономический университет» г. Нижний Новгород. Контакты: e-mail: kraynovaos@mail.ru

Kraynova Olga Sergeevna, Candidate of Economic Sciences, Associate Professor of the Institute of food technologies and design - a branch of the Nizhny Novgorod state University of engineering and Economics. Contacts: ORCID ID: 000-0002-9733-1089, researcher ID: D-7973-2019, e-mail: kraynovaos@mail.ru

Дата поступ.ления в редакцию: 15.01 .2020

После рецензирования: 13.02 .2020

Дата принятия к публикации: 03.03.2020 